\title{
The Prospect of Cultivating Maggot (Black Soldier Fly Larvae) to Build the Village Economy and Reduce Household Waste
}

\author{
Rusdi Faizin, Teuku Athaillah*, Nurul Munawarah \\ Study Program of Agribusiness, Faculty of Agriculture \\ Teuku Umar University \\ West Aceh, Indonesia \\ *athaillah.teuku@utu.ac.id
}

\begin{abstract}
Unconsciously, garbage and household waste are increasingly piling up and will continue to grow. The result will be a serious problem for the environment and public health. Maggot has two benefits at once, to act as a waste bioconversion agent as well as animal feed containing high protein. The purpose of this study is to observe how big the prospects for maggot cultivation are if cultivated simply by every village community. This research was conducted from May to October 2019, at Gampong Lueng Tanoh Tho village, Woyla Sub-district, West Aceh District. This research was conducted by conducting simple maggot cultivation trials. The trials were carried out with one repetition to get convincing results. The results showed prospects in terms of technical cultivation, maggot cultivation is completely easy and does not require much money. It only requires a container (used containers or used buckets). Judging from the prospect of profit, maggot cultivation is truly profitable since it costs little. There are many opportunities to market maggot either around the location of Gampong Lueng Tanoh Tho or at Meulaboh town with the target of catfish and tilapia farming farmers as well as bird keepers. In terms of the environment, Maggot is an important solution to keep the environment clean and healthy.
\end{abstract}

Keywords-maggot, prospect of profit, bioconversion agent

\section{INTRODUCTION}

One of the organic waste recycling techniques is bioconversion method. Bioconversion is the conversion of organic waste into a methane energy source through a fermentation process that involves living organisms [1]. This process is commonly known as anaerobic digestion. Organisms playing a role in the bioconversion process can be fungi or insect larvae. We often find this process in everyday life, such as stale food will grow mushrooms or tempe (fermented soybean) which uses fungus (yeast) in its making process, the making of compost from organic waste uses bacterial organisms as a remover, and there are also other destructive organisms such as insect larvae known as Hermetia Illucens or Black Soldier Fly (BSF). These BSF larvae are known as maggots or "maggots".
Maggot has two combined benefits which are as a waste bioconversion agent and as animal feed containing high protein. One of the substances that livestock need from feed is protein. However, feed containing high protein is relatively expensive. The high price of feed needed becomes a concern for breeders because it can cause the mismatched price of feed with the harvest. Therefore, breeders must look for other alternatives to meet the protein needs of livestock.

Maggot is a high source of animal protein because it contains a protein range of $30-45 \%$. This relatively high protein content is very potential as additional feed for rearing consumption fish. Maggots also contain antimicrobial and antifungal properties, as a result fish consuming maggots will be resistant to diseases caused by bacteria and fungi [2]

Unconsciously, garbage and household waste are increasingly piling up and will continue to grow. The result will be a serious issue for the environment and public health. This waste can be divided into two categories as organic and inorganic waste. The organic waste is waste or residual material originating from plants, animals or humans that is easily biodegradable. Meanwhile, the inorganic waste is waste that is difficult to decompose, such as plastic, glass, iron, etc. The everyday abundant organic waste can be processed in a variety of ways. One of them is by using it as a medium for cultivating maggot BSF flies (Black Soldier Fly larvae) [3]. This maggot can later be used as animal feed for both poultry and fish.

Black Soldier Fly (BSF) or in Latin known as Hermetia illucens is a species of flies from the order Diptera, included in the family Stratiomyidae with the genus Hermetia. BSF is a native fly from the American continent [4] and has spread almost all over the world [5]. The life phase of BSF is a complete metamorphosis cycle with 4 (four) phases such as egg, larva, pupa, and adult BSF [6]. Metamorphosis of BSF takes place in a susceptible period of fewer than 40 days, depending on environmental conditions and food intake [7]. 
The optimum freshly hatched BSF larvae live at a temperature of $28-35^{\circ} \mathrm{C}$ with a humidity of about $60-70 \%$ [8].

Maggot experiences five stages during its life cycle, the five stages are the adult phase, the egg phase, the larva phase, the pre-pupa phase, and the pupa phase. From the five stages, the stage after eggs is often used as fish feed. Black Soldier (BS) larvae have several characters including:

- Dewatering (absorbing water), and has the potential in organic waste management

- Can make a burrow for aeration of garbage

- Tolerant of $\mathrm{pH}$ and temperature

- Migrating closer to the pupa phase

- Hygienic, as control of house flies

- High protein content reaches $45 \%$ [9].

Furthermore, the purpose of this study is to observe how big the prospects of maggot cultivation are if cultivated simply by every village community. The prospects of maggot cultivation will be perceived from the aspects of technical cultivation, marketing, and the environment.

\section{RESEARCH METHODS}

This research was conducted from May to October 2019, at Gampong Lueng Tanoh Tho village, Woyla Sub-district, West Aceh District. This research was conducted by conducting a simple maggot cultivation trial. The trials were carried out with one repetition to obtain convincing results. Maggot cultivation trials were carried out to see how much maggot can be produced from garbage and household waste. From the maggot cultivation trials simply can be seen the cultivation prospects based on the perspectives of technical cultivation and the environment. Researchers also conducted interviews with villagers of Gampong Lueng Tanoh Tho to find out the amount of garbage and household waste produced per day in order to calculate the prospects in terms of profit and maggot marketing.

The procedure for conducting a simple maggot cultivation trial is as follows.

- Collecting information

- Planning a trial location

- Preparing tools and materials

- Conducting a 25-day cultivation trial

- Harvesting the first cultivated maggot results

- Repeating maggot cultivation trials

- Harvesting the second cultivated maggot results

\section{RESULTS AND DISCUSSION}

Prospects are opportunities or hopes, views (future) over possibilities that may occur. In economics, prospect is an image of a future, whether the business will run smoothly and gain a profit or vice versa. In this simple maggot cultivation experiment, the prospects to be noticed are from the aspects of technical cultivation, profit, marketing, and the environment.

\section{A. Prospects from the Technical Aspect of Maggot Cultivation}

Techniques in cultivating maggot are simply easy and not difficult. Maggot cultivation only requires simple media. Cultivation of BSF maggots can be done anywhere on a scale that fits the capabilities of the breeders. The ways how to make it is as follows: Household waste both in the form of vegetables and fruit waste material is cut into small pieces and put into a plastic container that has been perforated. Later, add a little water then coat with wet banana leaves or other leaves, and then covered with plywood. The container is allowed to be seized by BSF flies. For more details, it can be seen in the following figures.

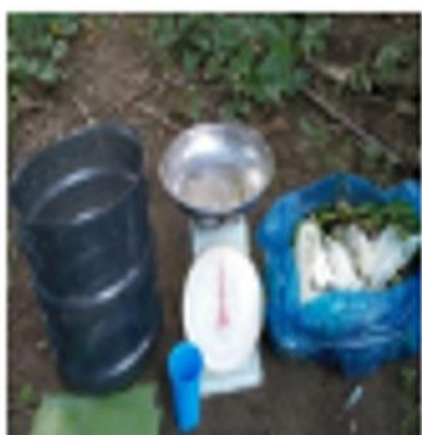

Fig. 1. Prepare the ingredients.

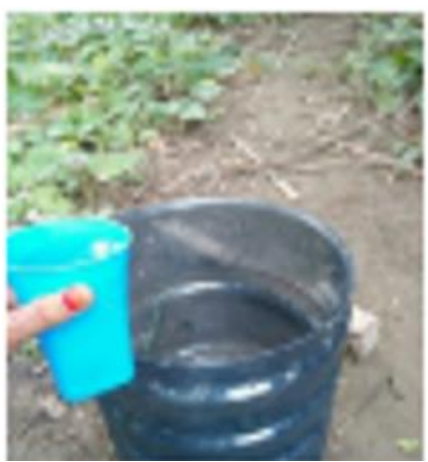

Fig. 3. The container is filled by water.

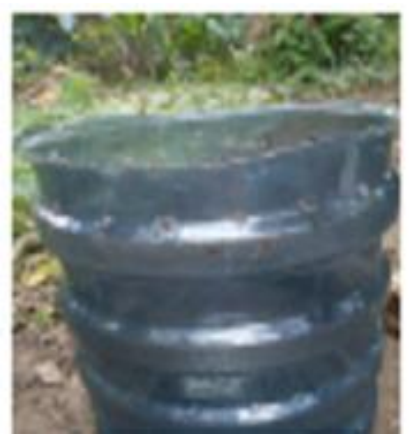

Fig. 2. Provide a container

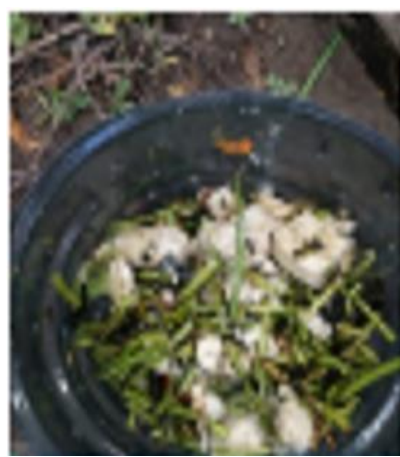

Fig. 4. The container is filled with organic waste 


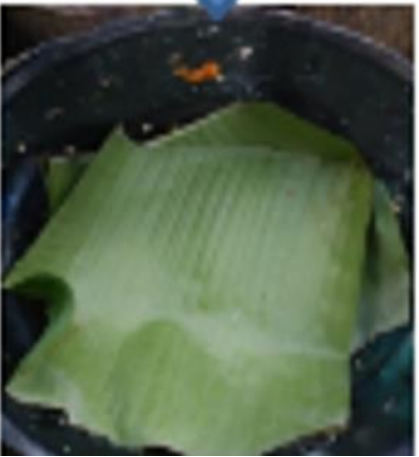

Fig. 5. Cover with leaves.

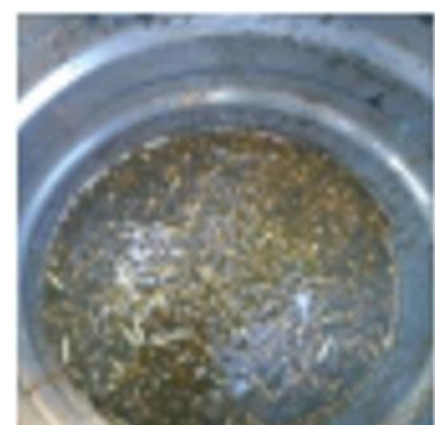

Fig. 7. Maggots are ready to be harvested.

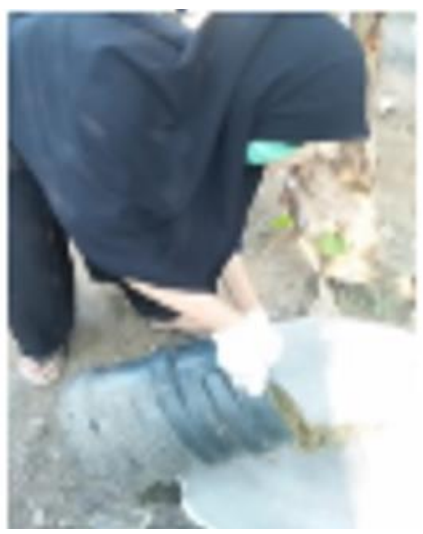

Fig. 9. Filter the maggots.

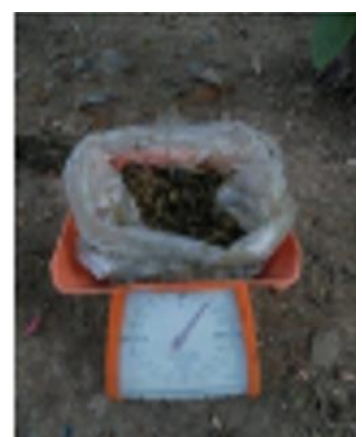

Fig. 11. Weigh the maggots.

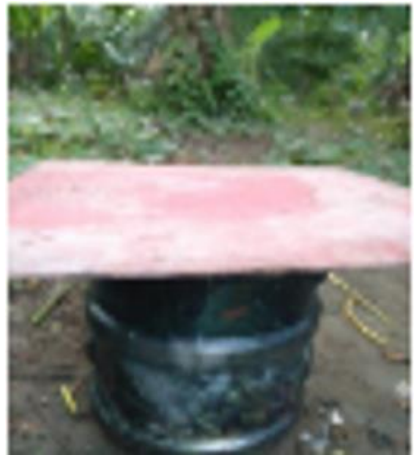

Fig. 6. Container is closed.

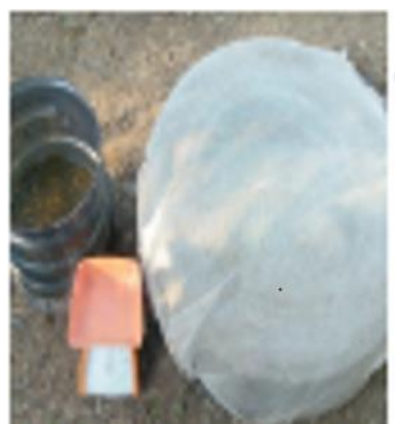

Fig. 8. Provide a filter.

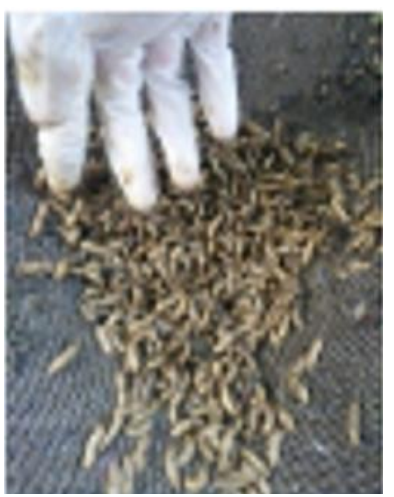

Fig. 10. Harvest the maggots.
As seen from the technical aspects of cultivation in Figure 1-11, maggot cultivation is completely easy and does not require much money. It only requires a container (used containers or used buckets). The container is then put in waste and household food scraps. Then wait for 20 - 25 days and maggots are ready to be harvested.

\section{B. Prospects from the Profit Aspect}

Business profits are the difference between the total revenue earned in the maggot business minus the total costs during the production process. Based on the trials conducted for 25 days, for $5 \mathrm{~kg}$ of garbage /household waste, it produces 2 ounces of maggots. The price of maggot / kg is IDR 10.00012.000

Based on the interview results of researchers with the Gampong Lueng Tanoh Tho villagers, it was found that the minimum average household waste per day was $2,5 \mathrm{~kg} /$ family. This waste can come from uneaten rice, stale vegetable curry, fish waste, fruit scraps, and other wastes. If the waste is collected in a container for 1 month, each household can collect a minimum of $75 \mathrm{~kg} / \mathrm{month}$, with $75 \mathrm{~kg}$ of garbage can produce $3 \mathrm{~kg}$ of maggots.

If the waste of the entire villagers totalling 186 families is collected in 1 month for the maggot cultivation, then at least $558 \mathrm{~kg}$ of maggots will be obtained with a selling price of IDR $10.000 / \mathrm{kg}$, it can earn IDR 5,580,000 / month.

\section{Prospects from the Marketing Aspect}

For maggot marketing, researchers perceived many opportunities to market maggots both around Lueng Tanoh Tho village location and to the town of Meulaboh. There are many catfish and tilapia ponds that are cultivated by villagers around Lueng Tanoh Thodi Village, Woyla Sub-district. Maggots can be used as alternative food or additional food for these catfish and tilapia. Considering the high protein content in maggots, the growth of catfish and tilapia fish will be much faster.

In addition, maggot can also be marketed for bird lovers in Woyla Sub-district and Meulaboh. For bird lovers, bird health is a top priority. Many bird lovers are willing to spend a lot of money to find the best and healthy food for their birds. The opportunity to market maggots to bird lovers is huge.

\section{Prospect from the Environmental Aspect}

Maggots can be produced from natural processes of organic waste from households such as wet food and vegetables perched by BSF flies. Organic waste becomes a growing medium for Maggots. In the cultivation business, maggots possess a positive influence on the environment as they can be used to reduce organic waste quickly and maintain the environmental cleanliness and health.

BSF maggots are more hygienic when compared to house flies (Musca $s p$ ) or green flies (Challipora $s p$ ). Up to now, maggots have not been detected as a cause of disease [10]. 
Maggots become an essential solution to keep the environment clean and healthy.

If the entire villagers of Gampong Lueng Tanoh Tho do maggot cultivation independently at their respective homes, it can be assured that the environment at Gampong Lueng Tanoh Tho will be cleaner. During the cultivation is carried out, it must be at a distance from the house in order to avoid possible odours generated from the garbage.

\section{CONCLUSION}

The research results show prospects in terms of the technical perspective of cultivation as maggot cultivation is completely easy and does not require a lot of money. It only requires a container (used containers or used buckets). Judging from the prospects for profit, maggot cultivation is truly profitable since it costs little. Many opportunities in marketing maggots both around Gampong Lueng Tanoh Tho village location and the town of Meulaboh targeting catfish and tilapia fish farmers as well as bird keepers. In terms of the environment, Maggot becomes an essential solution to keep the environment clean and healthy. In the future, a test of the research application can be conducted in the community.

\section{ACKNOWLEDGMENT}

The publication fund was provided by Teuku Umar University.

\section{REFERENCES}

[1] L. Newton, C. Sheppard, D.W. Watson, G. Burtle and R. Dove, "Using the black soldier fly, Hermetia illucens, as a value-added tool for the management of swine manure," Animal and Poultry Waste Management Center, North Carolina State University, Raleigh, NC, 2005.

[2] I. Indarmawan, "Environmental Monitoring of Perancak Estuary Based on the Distribution of Macrobenthos," Fisheries and Marine Scientific Journal, vol. 3, no. (2), 2014.

[3] Balitbangtan (BB Veteriner), Lalat Tentara Hitam Agen Biokonversi Sampah Organik Berprotein Tinggi [Online]. Retrieved from: http://www.litbang.pertanian.go.id/berita/one/2557/, 2016.

[4] S. Hem, S. Toure, C. Sagbla and M. Legendre, "Bioconversion of palm kernel meal for aquaculture: Experiences from the forest region (Republic of Guinea)," African Journal of Biotechnology, vol. 7, no. (8), 2008.

[5] H. Čičková, M. Kozánek and P. Takáč, "Growth and survival of blowfly Lucilia sericata larvae under simulated wound conditions: implications for maggot debridement therapy," Medical and veterinary entomology, vol. 29, no. (4), pp. 416-424, 2015.

[6] R. Popa and T. Green, DipTerra LCC e-Book 'Biology and Ecology of the Black Soldier Fly'. DipTerra LCC, 2012.

[7] L. Alvarez, The role of black soldier fly, Hermetia illucens (L.)(Diptera: Stratiomyidae) in sustainable waste management in Northern Climates, 2012.

[8] L.A. Holmes, S.L. Vanlaerhoven and J.K. Tomberlin, "Substrate effects on pupation and adult emergence of Hermetia illucens (Diptera: Stratiomyidae)," Environmental entomology, vol. 42, no. (2), pp. 370374, 2013.

[9] R.F. Melta, "Optimization of the Bioconversion Process Using Hermetia Illucens Mini Larvae to Meet Fish Feed Needs," Journal of Pros Sem Nas Masy Biodiv Indon, vol. 1, no. 1, 2015,

[10] S. Wangko, "Hermetia Illucens aspek forensik, kesehatan, dan ekonomi," Jurnal Biomedik: JBM, vol. 6, no. (1), 2014. 